\title{
PENERAPAN SYARIAT ISLAM
}

\author{
Azman
}

Fakultas Syariah dan Hukum UIN Alauddin Makassar

\begin{abstract}
Fundamentalist Islamic groups (often) are considered the most responsible for various bloody events in various parts of the world, including in Indonesia. Various terms are offered by thinkers, both non-Muslims and Muslims, to give only the most perfect description of this group. For example, radicalism groups (revolutionary Islam), Islamists, and Neo-fundamentalism. Actually, various terms are used interchangeably in the literature of contemporary Islamic movements. The Western world conditions it as radicalism and terrorism. In Middle Eastern countries, Islamic radicalism movements have taken root and have a long history. The emergence of the fundamentalist Islamic movement is a real symptom of what is called the rise of Islam. Revitalization of Islam is supported by a number of events and changes that affect countries that are predominantly Muslim. The most dramatic and spectacular manifestation of the emergence of this revival movement is the event of the Iranian Islamic revolution in 1979. The fundamentalist Islamic movement seeks to reflect on one view that Islam is a holistic religion that covers various aspects including in the political field. In this context, Islamic fundamentalism believes that religion and politics as a condition of necessity as reflected in the argument that states that al-Islam Diunun wa Dawlah, Islam is Religion and State.
\end{abstract}

\section{Keywords:}

Ideology, Religious Social Movement, Fundamentalism.

\begin{abstract}
Abstrak
Kelompok Islam fundamentalis (seringkali) dianggap sebagai pihak yang paling bertanggungjawab atas beragam peristiwa berdarah di berbagai belahan dunia, termasuk di Indonesia. Bermacam istilah ditawarkan oleh para pemikir, baik non-Muslim maupun Muslim, untuk (sekedar) memberikan deskripsi paling sempurna tentang kelompok ini. Misalnya, kelompok radikalisme (Islam revolusinoner), Islamist, dan Neo-fundamentalisme. Sebenarnya, beragam terma itu bersumsum-tulang karena digunakan secara bergantian dalam literatur gerakan Islam kontemporer, Barat mengkondisikannya sebagai radikalisme dan terorisme. Di negara-negara Timur Tengah, gerakan radikalisme Islam telah berakar urat dan memiliki sejarah yang cukup panjang. Munculnya gerakan Islam fundamentalis
\end{abstract}


merupakan suatu gejala riil dari apa yang disebut sebagai kebangkitan Islam. Revitalisasi Islam didukung oleh sejumlah peristiwa-peristiwa dan perubahan- perubahan yang mempengaruhi negara-negara yang mayoritas penduduknya beragama Islam Islam. Manifestasi yang paling dramatis dan spektakuler dari kemunculan gerakan kebangkitan ini adalah peristiwa revolusi Islam Iran pada 1979. Gerakan Islam fundamentalis berusaha merefleksikan satu pandangan bahwa Islam merupakan agama holitik yang meliputi berbagai aspek termasuk di bidang politik. Dalam konteks ini, fundamentalisme Islam berkeyakinan bahwa agama dan politik sebagai suatu kondisi keniscayaan sebagaimana terefleksi dalam dalil yang menyatakan bahwa, al-Islam Di- nun wa Dawlah, Islam is Religion and State.

\section{Kata Kunci:}

Ideologi, Gerakan Sosial Keagamaan, Fundamentalisme.

\section{A. PENDAHULUAN}

da hipotesis dari Azyumardi Azra, bahwa fundamentalisme, terutama yang
radikal atau ekstrim sepanjang sejarah tidak terlalu berhasil. Jika sejarah
adalah cermin, lanjut Azra, maka cukup sah bagi orang bersikap skeptis terhadap masa depan fundamentalisme radikal.

Setidaknya ada dua hal yang menarik dari hipotesis Azra ini. Pertama, vrarian radikal gerakan fundamentalisme. Kedua, masa depan fundamentalisme radikal. Kedual hal ini menarik dijadikan sebagai titik masuk dalam membahas fenomena fundamentalisme agama di indonesia. Sejak berakhirnya rezim Orde Baru pada 1998, kehidupan keagamaan terutama di kalangan masyarakat islam terjadi banyak perubahan. Salah satunya yang menarik perhatian publik, adalah semakin maraknya gerakan kelompok fundamentalisme. Sebenarnya keberadaan kelompok fundamentalisme merupakan hal yang wajar, karena seperti dikemukakan oleh Ian Adams, fundamentalisme dapat ditemukan dalam berbagai macam lingkungan dan tampil dalam berbagai bentuk yang beragam. Tetapi perkembangan fundamentalisme agama yang terjadi dilingkungan masyarakat islam di indonesia tetap memiliki daya tarik untuk dikaji lebih jauh, karen ternyata meruntuhkan tesis sejumlah ahli yang mengamati perkembangan islam di indonesia. Kaum fundamentalisme seringkali mengusung tema ideologi islam dalam setiap aksinya, dengan suatu tujuan yang menawarkan islam sebagai ideologi alternatif. Tema tersebut menarik jika dikonfirmasi dengan tesis dari Kuntowijoyo. Dalam analisi Kuntowijoyo, umat islam di indonesia sebenarnya sudah meninggalkan periode ideologi sejak 1985, dan memasuki periode baru yang disebut dengan periode ilmu. Dua periode ini digambarkan secara paradoksal oleh Kuntowijoyo. Pada periode ideologi, islam bersifat tertutup. Orientasi perjuangannya lebih menyepit ke politik. 
Sedangkan periode ilmu, umat islam lebih terbuka (inklusif). Orde Baru berakhir, disamping umat islam kembali terobsesi dengan politik formal, juga ditandai dengan munculnya gerakan kelompok fundamentalisme yang secara terbuka mngusung tema ideologi islam.

Tentu agak susah membuat prediksi terhadap masa depan kelompok fundamentalisme di Indonesia; apakah nanti mereka berhasil antara lain melakukan obyektivitasi terhadap Ideologi Islam, atau tidak? tetapi jika yang dimaksud dengan kelompok fundamentalisme adalah varian ekstrim-radikal, dalam pengertian varian fundamentalisme yang mensahkan pemggunaan cara kekerasan fisik, memang banyak orang yang bersikap skeptis, bahkan juga apatis. Sebut saja aksi kekerasan berupa pengeboman yang terjadi di Legian, Kuta. Bali, pada 12 Oktober 2002, dan di Hotel J.W. Marriot pada 5 Agustus 2003. Beberapa analisis keagamaan-meminjam istilah Azra-fundamentalis ekstrim-radikal. Juga hujatan, karena korban yang ditimbulkan tidak terhitung nilainya, melahirkan oerubahan seperti yang dikehendaki oleh ideologi tentu juga dari pemerintah, fundamentalisme ekstimradikal tidak memiliki masa depan. Sampai disini, keraguan Azra terhadap masa depan fundamentalisme radikal-ekstrim menemukan pembenaran. ${ }^{1}$

\section{B. PEMBAHASAN}

\section{Konstruksi Ideologi Kelompok Keagamaan}

Secara gerakan sosial tanpa adanya ideologi hanya akan menghadapi ketidakpastian yang berkepanjangan. Karena itu gerakan sosial perlu merumuskan kerangka ideologinya yang berisi: pertama, pernyataan tujuan gerakan; kedua, kumpulan kritik dan penilaian terhadap struktur yang akan diubah; ketiga, kumpulan doktrin yang mampu menjustifikasi tujuan gerakan; keempat, seperangkat kepercayaan yang berhubungan dengan kebijakan, taktik, dan pelaksaan gerakan; kelima, mitos gerakan. ${ }^{2}$

Pertanyaan yang muncul kemudian ialah, definisi ideologo mana yang diadaptasi oleh Hizbut Tahrir dan Majelis Mujahidin Indonesia? Karena harus diakui, para akademisi dan tokoh gerakan sosial di dunia saling berbeda pendapat dalam mendefinisikan kata ideologi, sehingga penggunaan kata ideologi oleh suatu kelompok perlu ditinjau terlebih dahulu konteks ideologi yang diadaptasi oleh kelompok tersebut.

\section{a. Pengertian Ideologi}

Istilah ideologi pertama kali ditemukan oleh Desstutt de Tracy pada tahun 1796 dengan maksud memberi nama terhadap ilmu baru yang dirancang mengenai analisi sistematik tentang ide dan sensasi, tentang makna turunnya, kombinasinya 2010) h.2

${ }^{1}$ Arifin Syamsul, Ideologi dan Praksis Gerakan Sosial Kaum Fundamentalis, (Malang: UMM Press,

${ }^{2}$ Herbert Blumer, Social Movement dalam principal of Sociology, ed. Alfred Mclung Lee (New York; Barnes\&Noble, inc. 1966) h.199 dalam Syamsul Arifin, op. cit., h.55-56 
dan akibat yang ditimbulkannya. De Tracy berpandangan bahwa pengetahuan terhadap benda tidak boleh diperoleh secara langsung dari benda itu sendiri, ttapi hanya melalui ide-ide yang terbentuk berdasarkan sensasi seseorang terhadap benda-benda tersebut. Dalam pandangan De Tracy, untuk menganalisis ide dan sensasi secara sistematis, dibutuhkan suatu disiplin ilmu poengetahuan ilmiah yang kuat dan dapat menarik kesimpulan secara lebih praktis. Maka ia mengusulkan nama pengetahuan ilmiah yang dimaksud dengan ideologi - ilmu tentang ide.

Dewasa ini, kata ideologi bukanlah istilah asing bagi masyarakat, khususnya bagi kalangan terpelajar. Pengertian sederhana dari ideologi ialah paham, ide, atau pemikiran. Dengan pengertian diatas, maka pada dasarnya semua orang mempunyai ideologi tetapi kontek penggunaan istilah ideologi tidak sesederhana dalam pengertian tersebut. Karena penggunaan kata ideologi oleh para tokoh pergerakan sosial selama beberapa dekade mengalami pergeseran dari makna awalnya. Menurut John B. Thompson, istilah ideologi sering digunakan dalam dua cara. Cara yang pertama, ideologi digunakan dalam konsep yang netral (neutral conception). Dengan cara ini, ideologi dipahami tidak lebih dari sekedar sistem berfikir, sistem kepercayaan, prakik-praktik simbolik yang berhubungan dengan tindakan sosial dan politik. Cara kedua, ideologi dipahami secara kritis (critical conception of ideology), dalam konteks ini ideologi selalu dikaitkan dengan praktik relasi kekuasaan asimetris dan dominasi kelas. ${ }^{3}$

Adalah Karl Marx, tokoh sosialis yang menjadikan ideologi memperoleh kemaknaan baru sebagai sarana kritik, ide yang semula dalam analisi ideologi dipandang sebagai sesuatu yang biasa-biasa saja, oleh Marx dikaitkan dengan relasi antar kelas dalam masyarakat. Maksud Marx tentang ideologi adalah bahwa ideologi adalah indusi politik dan kesadaran palsu yang dihasilkan oleh pengalaman sosial suatu kelas. ${ }^{4}$ atau menurut Larrain, ideologi digunakan sebagai alat penipuan (oleh kelas dominan/penguasa) untuk memutar balikkan pemahaman orang mengenai realitas sosial. ${ }^{5}$

Gramsci dan Lenin, keduanya adalah murid dari Karl Marx, mengembangkan pengertian positif terhadap ideologi, sehingga ideologi tidak selalu berkonotasi negatif. Bagi mereka, ideologi dipandang sebagai kumpulan ide yang menyajikan dan mewujudkan kepentingan khusus kelas sosial. Berbeda dengan Marx, ideologi dalam pandangan Lenin dan Gramsci memiliki fungsi praktis sebagai pemikiran, teori, dan sikap untuk membela dan memajukan kepentingan-kepentingan kelas sosial tertentu. ${ }^{6}$

\footnotetext{
${ }^{3}$ John B Thomson, Analisi Ideologi: Kriti Wacana Ideologi-ideologi Dunia, (Yogyakarta: Ircisod, 2003) h.17 dalam Syamsul Arifin. Ideologi dan Praksis. h. 30

${ }^{4}$ Lyman Tower Sargent, Ideologi-ideologi Politik Kontemporer: Sebuah Analisis Komparatif (Jakarta: Erlangga,1987), hal.3

5 Jorge Larrain, Konsep ideologi (Yogyakarta: LKPSM, 1986) H.2.

${ }^{6}$ Andrew heywood, political Ideologies: An Introduction (London: Macmillan Education Ltd., 1992) h. 7
} 
John B Thompson melengkapi gagasan Marx dengan mengembangkan konsep yang disebut dengan cara kerja ideologi dalam melakukan relasi dominan. Konsep ini oleh Thompson dikaitkan juga dengan bentuk-bentuk simbol tertentu yang digunakan untuk memperkuat dominasi. Ada lima model dan kerja ideologi serta tiga belas bentuk strategi konstruksi simbol yang ditemukan oleh Thompson dalam praktik relasi dominasi seperti pada tabel dibawah ini. ${ }^{7}$

b. Strategi Konstruksi Simbol

$\begin{array}{ll}\text { Legitimasi } & \text { - Rasionalitas } \\ & \text { - Universalisasi } \\ & \text { - Narativisasi } \\ \text { Penipuan } & \text { - Pemindahan } \\ & \text { - Eufemisasi } \\ & \text { - Kiasan (Sinekdok, Mentomini, Metafor) } \\ \text { Unifikasi } & \text { - Standarisasi } \\ & \text { - Simbolisasi dari Kesatuan } \\ \text { Fragmentasi } & \text { - Diferensi } \\ & \text { - Ekspurgasi yang lain } \\ \text { Reifikasi } & \text { - Naturalisasi } \\ & \text { - Eternalisasi } \\ & \text { - Normalisasi }\end{array}$

Sistem paham yang melekat pada ideologi bisa diperjelas lagi unsur-unsur yang ada didalamnya yaitu:

a. Pandangan yang konfrehensif tentang manusia, dunia, dan alam semesta dalam kehidupan.

b. Rencana penetaan sosial politik berdasarkan paham tersebut.

c. Kesadaran dan pencanangan dalam bentuk perjuangan melakukan perubahaperubaha berdasarka paham dan rencana ideologi tersebut.

d. Usaha mengarahkan masyarakat menerima ideologi tersebut yang menuntut loyalitas dan keterlibatan para pengikutnya.

e. Usaha memobilitasi seluas mungkin para kader dan massa yang akan menjadi pendukung Ideologi tersebut. ${ }^{8}$

Austin Ranny memilah-milah ideologi dalam empat komponen dasar. Pertama, nilai (value): kedua, visi tentang kehidupan sosial yang ideal: ketiga, konsep tunggal kehidupan manusia (human nature): keempat, strategy for action sehingga bisa menjadi kenyataan. Masih dalam buku yang sama, pakar ilmu politik Roy C. Macridis memaparkan empat aspek kriteria ideologi, yaitu: comrehensiveness (menyeluruh dan luas), pervasiveness (berpengaruh kepada seluruh sendi-sendi

\footnotetext{
${ }^{7}$ Ibid., Syamsul Arifin h. 31

${ }^{8}$ Riberu dkk, Menguak Mitos-Mitos Pembangunan: telaah Etis dan Kritis. (Jakarta: Gramedia,1986) h.5
} 
masyarakat), estensiveness (diikuti oleh banyak orang dan memainkan peranan besar dalam percaturan politik suatu bangsa), dan intensiveness (memberikan suatu komitmen yang kuat bagi pengikut setianya dan memberikan pengaruh yang signifikan terhadap keyakinan dan tindakan politiknya. ${ }^{9}$

Dalam konteks Islam perdebatan mengenai kemungkinan islam dijadikan ideologi agaknya sudah tidak relevan lagi, sebab, faktanya menunjukkan bahwa pada masing-masing kelompok dan gerakan keagamaan dikalangan masyarakat Islam kelompok dan gerakan keagamaan dikalangan masyarakat Islam telah muncul berbagai ideologi. Dalam kontek islam, kebutuhan terhadap ideologi bukan sematamata untuk menemukan dan meneguhkan suatu identitas, tetapi lebih penting lagi, dan sekaligus sebagai implikasi dari peneguhan identitas, ideologi digunakan sebagai titik tolak ukur untuk melakukan perubahan. Alhasil, ideologi dalam islam digunakan sebagaimana fungsi ideologi pada umumnya, yaitu:

a. Strukturkognitif, keseluruhan pengetahuan yang dapat merupakan landasan untuk memahami dan menafsirkan dunia dan kejadian-kejadian dalam alam sekitarnya.

b. Orientasi dasar yang membuka wawasan yang memberikan makna serta menunjukan tujuan dalam kehidupan manusia.

c. Norma-norma yang menjadi pedoman dan pegangan bagi seseorang untuk melangkah dan bertindak.

d. Bekal dan jalan bagi seseorang untuk menemukan identitasnya.

e. Kekuatan yang mampu memberi semangat dan mendorong seseorang untuk menjalankan kegiatan dan mencapai tujuan.

f. Pendidikan bagi seseorang atau masyarakat un tuk memahami, menghayati, serta memolakan tingkah lakunya sesuai dengan orientasi dan norma-norma yang terkandung didalamnya. ${ }^{10}$

Aspek ideologi dalam islam memiliki daya tarik untuk dikaji lebih lanjut karena adanya polarisasi dalam orientasi ideologi gerakan islam. Studi yang dilakukan R. Hrair Dekmejian bisa dijadikan rujukan untuk menggambarkan polarisasi tersebut. Ia mengambarkan polarisasi ideologi gerakan islam kedalam empat kategori. ${ }^{11}$

Pertama ialah gradualis-adaptasionist, dengan orientasi ini gerakan islam memiliki cara-cara bertahap dalam mempertinggi kesadaran keagamaan dikalangan masyarakat, sementara disisi terus berupaya mendorong pelaksanaan syariat oleh negara.

\footnotetext{
${ }^{9}$ Miftah Toha, Birokrasi Politik di Indonesia, (Jakarta: Rajawali, 2003) h. 83-86.

10 Soerjanto Poespowardojo, dalam Oetojo Oesman dan Alfian, Pancasila Sebagai Ideologi dalam Berbagai Bidang Kehidupan bermasyarakat, Berbangsa, dan Bernegara, (Surabaya: Karya Anda, 1993) h. 48

11111 R. Hrair Dekmeijian, Islamic Revival: Catalysts, Categories, and Consequences, dalam The politics of islamic revivalism, ed. Shirean T. Hunter (Bloomington anf Indianapolish, Indiana University Press, 1998) h.12-14
} 
Kedua ialah Syi'ah Revolusioner. Kategori ini merujuk pada keberhasilan Syi'ah di Iran yang sukses menggerakkan revolusi untuk menggulingkan Shah Iran pada tanggal 11 Februari 1979 yang beusaha mengadopsi sukularisme, yang kemudian mendatangkan kecaman dari para pemuka agama hingga membuatnya digulingkan.

Ketiga ialah Sunni Revolusione. Dikatakan Sunni karena gerakan ini dirintis ileh imam-imam besar dari kalangan Sunni. Seperti Ibn Hambali, Ibn Taymiyah dan Ibn Qayim, Ibn Kathir, Nawani, Abd al-Wahab, dan lainnya. Para iamam ini mempunyai komitmen terhadap pembaharuan ummat dengan kembali ke akar-akar islam; advokasi, militansi, dan jihad dalam mempertahankan islam; dan kesiapan menghadapi otoritas keagamaan dan politik, serta kesediaan menderita mempertahankan keyakinan agama mereka.

Keempat ialah Mesianis Primitif. Gerakan dalam kategori ini disebut sebagai gerakan yang paling puritan dan berusaha mencontoh kehidupan Nabi dan bentuk kehidupan komintas Islam pertama serta menentang berbagai bentuk inovasi modern.

Tabel pengklasifikasian Gerakan Kelompok Islam ${ }^{12}$

\begin{tabular}{|l|l|}
\hline Orientasi ideologi & Gerakan Islam \\
\hline Gradualis- & Ikhwan Al-Muslimin (Mesir, Irak, Negara Teluk, Yordania, \\
Adaptasionis & Afrika Utara) \\
Syi'ah Revolusioner & Jama'ah Islam (Pakistan) \\
& Partai Republik Islam (Iran) \\
& Hizb al-Dakwah (Irak) \\
& Hizbullah (Libanon) \\
& Jihad al-Islam (Libanon) \\
Sunni-Revolusioner & Organisasi Pembela Islam (Mesir) \\
& Ikhwan al-Muslimin (Suriah) \\
& Jama'ah Abu Dzar (Suriah) \\
& Hibut Tahrir (Yordania, Suriah) \\
& Al-Ikhwan (Saudi Arabia) \\
& Takfir wa al-Hijrah (Mesir) \\
& Mahdiyya (Sudan) \\
& Jama'ah al-Muslimin li al-Takfir (Mesir) \\
\hline
\end{tabular}

\section{Gerakan Sosiologis Kelompok Islam}

Sebagai fenomena yang telah berlangsung lama dan tersebar pada semua agama yang ada di muka bumi, kajian tentang fenomena fundamentalisme menjadi sesuatu ya ng menaruk. Pembahasan ini selanjutnya coba memberikan penafsiran dan sudut pandang sosiologis untuk memahami faktorfaktor sosiologis muncuknya

\footnotetext{
${ }^{12}$ Syamsul Arifin, op. cit., h.31
} 
fundamentalisme agama. Penjelasan semacam ini dipandang perlu, karena munculnya fundamentalisme agama tidak saja disebabkan oleh dorongan yang terdapat dalam ajaran itu sendiri, melainkan juga bertali-temali dengan berbagai faktor sosiologis juga diharapkan bisa memahami adanya hubungan yang dialektis antara agama dan realitas sosial yang dapat membentuk fundmentalisme agama sebagai gerakan sosial.

Salah satu cara memahami fenomena fundamentalisme dari sudut persfektif sosiologi adalah dengan menempatkannya sebagai bagian dari gerakan sosial. Cara ini memang akan membuka peluang munculnya kritik karena memang jarang sekali agama dikaitkan dengan gerakan sosial bertitik sosial - yang dikemukakan oleh Karl Marx, dimana kesadaran yang mendorong gerakan sosial ini adalah kondisi eksploitasi dari para pemilik modal. Dengan kata lain, pendekatan Marxis terhadap gerakan sosial terlalu menekankan ekonomi dan kelas sebagai faktor utama perubahan. ${ }^{13}$

Kelemahan dalam pendekatan Marxis, mendorong munculnya paradigma gerakan sosial baru. Paradigma ini menurut Laode Ida tidak melihat gerakan sosial hanya sebatas pada konflik material, melainkan meluas sesuai dengan dinamika perkembangan masyarakat kontemporer. Menurut paradigma ini, gerakan sosial dilakukan dengan cara melibatkan entitas sosial yang disebut dengan civil society. Jadi jika adalam paradigma gerkan sosial lama, buruh ditempatkan entitas yang memiliki kesadaran melakukan perubahan, maka dalam paradigma pergerakan justru berasal dari para kelas menengah terdidik ketimbang kelas pekerja. ${ }^{14}$

\section{a. Faktor-Faktor yang Mendorong Gerakan Sosial}

Gerakan fundamentalisme akan terus menjadi fenomena sosial sepanjang tersedia faktor-faktor sosial yang mendorongnya. Bahkan situasi yang berkembang dewasa ini, bisa berpotensi menjadi gerakan yang meniscayakan unculnys gerakan fundamentalism, yang disisi lainnya, telah menimbulkan berbagai macam persoalan fundamental dalam kehidupan manusia, meskipun disis yang lainnya lagi, memberikan manfaat yang demikian besar bagi kehidupan manusia, terutama manfaat yang diperoleh berkat kemajuan di bidang ilmu pengetahuan teknologi. Keberadaan ini nampaknya begitu mendominasi kehidupan manusia. Tak berlebihan bila John Naisbitt mengatakan, saat ini manusia sedang berada dalam "zona mabuk teknologi". ${ }^{15}$

Tetapi, berkelindan dengan kmajuan di bidang ilmu pengetahuan dan teknologi, sejumlah krisis fundamental mendera kehidupan manusia seperti diungkap oleh Nurcholish Madjid, yaitu: ${ }^{16}$

\footnotetext{
${ }^{13}$ Jan Pakulski, Sosial movement and class: The Decline of the Marxist Paradigm, h.52

${ }^{14}$ Laode Ida. Gerakan Sosial Kelompok Nahdatul Ulama (NU) Progresif, Disertai Universitas Indonesia, Jakarta, 2001 h. 36 dan 38.

${ }^{15}$ John Naisbitt, Nana Naisbitt, dan Doulas Philip. High Tech, High Touch: Pencarian Makna di tengah Perkembangan Pesat Teknologi (Bandung: Mizan, 2001) h.23

${ }^{16}$ Nurcholish Madjid, Kaki Langit Peradaban Islam (Jakarta: Paramadina, 1997) h. 194-195
} 
- Deprivasi relatif, yaitu perasaan teringkari, tersisihkan atau tertinggal pada orang lain dan kalangan tertentu dalam masyarakat akibat tidak dapat mengikuti laju kemajuan, dan kesulitan menyesuaikandiri dengan perubahan itu.

- Dislokasi, yaitu perasaan tidak punya tempat dalam tatanan sosial yang sedang berkembang.

- Disorietasi, yaitu perasaan tidak mempunyai pegangan hidup akibat yang ada tidak lagi bisa dipertahankan karena tidak cocok.

- Negativisme, yaitu perasaan yang mendorong kearah pandangan yang serba negatif kepada tatanan yang sudah mapan, dengan sikap-siakp tidak percaya, curiga, bermusahan, melawan, dan lain-lain sebagainya.

Nurcholish madjid kemudian mengingatkan, jika krisis yang ditimbulkan oleh kemajuan tidak segera ditangani akan menciptakan lahan subur bagi munculnya gejala-gejala radikalisme, fanatisme, sektarianisme, dan lainnya. Menyebut agama sebagai suatu satunya faktor penggerak gerakan sosial memang beresiko terjadinya penarikan kesimpulan yang berlebihan. Pandangan yang proporsional adalah dengan meletakkan agama bersama-sama dengan variabel sosial lainnya yang menggerakkangerakan sosial. Neil J. Smelser berhasil menemukan enam faktor determinan penyebab munculnya gerakan sosial. Dalam Pandangan smelser keenam faktor tersebut saling terkait dalam terjadinya gerakan sosial. Keenam faktor tersebut sebagai berikut: ${ }^{17}$

- Structural Condusiviness. Gerakan sosial bermula dari adanya struktur yang mendukung. Dengan mengambil contoh perubahan yang terjadi di indonesia struktur pendukungnya adalah munculnya krisis multi dimensi. Akumulasi krisis ini menjadi struktur kondusif terhadap munculnya gerakan sosial. Hal yang sama terjadi juga pada gerakan sosial keagamaan. Munculnya gerakan sosial keagamaan juga diawali oleh adanya krisis antara tuntutan doktrin agama dengan praktiknya. Pada kasus gerak islam modern misalnya, kondisi krisis yang menjadi pemicu munculnya gerakan ini adalah keterbelakangan ummat islam setelah tidak lagi konsisten dengan ajaran islam sebagaimana dalam alquran dan al-sunnah.

- Structural Stain. Gerakan sosial semakin tidak terbendung apabila struktur kondusif menimbulkan ketegangan struktural. Dengan adanya krisis ekonomi, misalnya daya beli masyarakat turun, daya serap perusahaan terhadap tenaga kerja maka terjadilah pengangguran. Dalam kasus seperti ini, social malayse tidak dapat dihindarkan. Ketegangan, bahkan konflik, terjadi dimana-mana. Keadaan seprti ini dapat mempercepat gerakan sosial.

${ }^{17}$ James W. Vander Zanden, Sociology the Core ( New York: McGraw-Hill Publishing Company, 1990) h. $371-373$ 
- The Growth of A Generalized Belief. Ketegangan struktural menurut smelser belum begitu mencukupi dalam menghasilkan tindkan kolektif. Maka agar gerakan sosial bisa diwujudkan, diperlukan penjelasan mengenai permasalahan dan solusinya. Dalam konteks ini, interaksi sosial snagat diperlukan untuk saling bertukar fikiran dalam merespon persoalan yang dihadapi bersama.

- Precipatating Factor. Dari segi waktu, gerakan sosial seringali membutuhkan waktu yang lama. Tetapi gerakan sosial bisa dipercepat jika ada faktor yang mendukungnya, faktor-faktor itu bisa berupa peristiwa, bisa juga dalam bentuk kehadiran tokoh kharismatik.

- The Mobilization of Farticipan for Action. Terjadinya gerakan sosial sangat tergantung juga pada tersedianya kelompok yang bisa diorganisasi dan dimobilisasi untuk melakukan tindakan-tindakan tertentu. Pada tahapan ini, pemimpin dan komunikasi serta suplay dana sangat dibutuhkan bagi eksistensi gerakan sosial.

- Opration of Control. Tidak seperti faktor determinan lainnya kontrol sosial juga justru mencegah, menyelah, dan menghalangi gerakan sosial. Kontrol ini biasanya dilakukan oleh negara. Ada dua bentuk kontrol terhadap gerakan soisal dari pemerintah. Kontrol pertama berbentuk upaya pencegahan terhadap munculnya tindakan kolektif dengan cara mengurangi faktor pendukung dan ketegangan strukturan seperti melalui peningkatan kesejahteraan. Kontrol kedua dengan cara menekan pelaku kolektif setelah gerakan dimulai seperti mengerahkan petugas keamanan dan menerapkan jam malam. Tekanan ini tidak selamanya efektif. Bahkan banyak kasus menunjukkan semakin mendapat tekanan semakin mempercepat terjadinya gerakan sosial.

\section{b. Tipe-tipe Gerakan Sosial}

Fundamentalisme agama tidak muncul dalam ruang hampa. Meskipun pertimbangan keagamaan tetap menempati peran utama dalam fundamentalisme, tidak boleh dilewatkan juga realitas dan perkembangan yang ada di luar agama. Gerakan fundamentalisme islam pada dasarnya muncul karena adanya pengaruh luar, ksususnya disebabkan oleh penetrasi barat terhadap umat islam dalam sebuah aspek kehidupan. Sehingga menyebabkan keterbelakangan ummat islam.

John J. Macionis membagi tipe gerakan sosial dala beberapa tipe yaitu: ${ }^{18}$

- Transformative social movement (gerakan sosial transformatif), merupakan gerakan untuk merubah masyarakat secara menyeluruh.

- Reformative sosial movement (gerakan sosial reformatif), merupakan gerakan untuk merubah masyarakat dari segi-segi tertentu.

- Alterative/Alternative sosial movement (gerakan sosial alteratif/alternatif), merupakan gerakan yang bertujuan merubah sebagian perilaku perorangan.

${ }^{18}$ John J. Macionis, Sociology (New Jersey: Prentice Hall, 1991) h.601 
- Redemtive Sosial movement (gerakan sosial redemtif), merupakan gerakan yang dimaksudkan untuk menyelamatkan masyarakat dari pandangan hidup yang dipandang korup dan tidak bermoral.

- Revolutionary Social Movement (gerakan sosial revolusioner), merupaka gerakan untuk melakukan perubahan terhadap seluruh tatanan sosial seperti sistem politik dan sistem sosial. ${ }^{19}$

\section{c. Klasifikasi Gerakan Sosial}

Menilik kajian teologi politik dan sosial agama maka istilah fundamental menjadi salah satu konsep yang muncul selain konsep modernisme. Kedua konsep ini pada mulanya dimunculkan oleh akademisi barat dalam konteks sejarah keagamaan mereka sendri. ${ }^{20}$ Modernisme diartikan sebagai aliran keagamaan yang melakukan penafsiran terhadap doktrin agama kristen untuk menyesuaikan dengan perkembangan pemikiran modern, sedangkan fundamentalisme dianggap sebagai aliran yang berpegang teguh pada "fundament" agama kristen melalui penafsiran terhadap kitab suci agama itu secara rigid dan literalis.

Istilah diatas menjadi sering dipakai belakangan ini oleh para ilmuan dalam menganalisis fenomena keberagamaan orang-orang islam, yang juga memperlihatkan sikap dan perilaku yang kaku dalam menerjemahkan nilai-nilai yang terkandung dalam kitab sucinya, baik yang tertulis dalam al=quran maupun yang telah dicontohkan oleh nabi muhammad saw pada periode awal islam. ${ }^{21}$ Tentu saja pelabean ini mendapatkan penolakan dari sebagian umat islam yang memang tidak pernah mengenal istilah fundamentalisme dalam literatur islam, karena islam tidak pernah mengenyam situasi dan konteks sebagaimana munculnya gerakan fundmentalisme itu sendri. Yang mereka ketahui ialah bahwa fundamentalisme adalah produk budaya barat yang dipaksakan untuk diterapkan pada situasi-situasi khusus masyarakat muslim modern, dan bernuansa politik tertentu. Tetapi, sebagian kalangan memandangnya sebagai hal yang wajar, dengan alasan bahwa fenomena fundamentalisme merupakan masalah klasik semua agama, tidak terkecuali agama Islam. $^{22}$

Hingga saat ini penggunaan istilah fundamentalisme memang mengandung kontroversi. Banyak kalangan dari ilmuan memilih tidak menggunakan istilah fundamentalisme. Misalnya John L. Esposito dan Mark Jurgensmeyer. Jurgensmeyer mengemukakan tiga alasan penolakannya menggunakan istilah fundamentalisme, ${ }^{23}$ yaitu:

${ }^{19}$ Kumanto Sunanto, Pengantar Sosiologi (Jakarta: Lembaga Penerbit Fakultas Ekonomi Universitas Indonesia, 1993) h. 202

${ }^{20}$ Yusril Ihza Mahendra, Fundamentalisme dan Modernisme Politik Islam (Jakarta: Paramadina,1999)

${ }^{21}$ Syarifuddin Jurdi, Pemikiran Politik Islam Indonesia: Pertauan Negara, Khalifah, Masyarakat Madani dan Demokrasi. (Yogyakarta: Pustaka Pelajar, 2008) h. 307-308

${ }^{22}$ Syamsul Arifin, op. cit., h. 41.

${ }^{23}$ Mark Jurgensmeyer, Menantang Negara Sekuler: Kebangkitan Global Nsionalisme Religius (Bandung: Mizan, 1998) h.17-18 
- Istilah fundamentalisme bersifat merendahkan. Ia merujuk kepada orang-orang yang memegang literalisme religius yang tidak toleran, merasa paling benar, dan nyaris dogmatis. Istilah ini lebih bersifat tuduhan ketimbang penjelasan.

- Fundamentalisme merupakan kategori yang tidak tepat untuk membuat perbandingan lintas kultural karena berasal dari tradisi kegamaan protestan, sehingga terdapat kesulitan kalau diterapkan kepada kelompok lain.

- Istilah sundamentalisme cenderung tidak mengandung gerakan politik, dan lebih mementingkan unsur keagamaan ketimbang urusan duniawian.

Esposito sendiri, ketika membicarakan Gerakan Islam Kontemporer, lebih suka menggunakan istilah Kebangkitan Islam atau Aktivis Islam daripada fundamentalisme islam. Alasan penolakan elposito terhadap istilah fundamentalisme ialah: ${ }^{24}$

- Istilah fundamentalisme memiliki pengertian yang terlalu generik karena semua yang menghendaki untuk kembali ke kepercayaan dasar atau dasar-dasar suatu agama dapat dikatakan fundamentalisme.

- Pengertian dan persepsi tentang fundamentalisme sangat dipengaruhi oleh protestanisme Amerika.

- Fundamentalisme kerap disejajarkan dengan aktivitas politik.

Sangat sayangkan beberap umat muslim dengan gegabah menggunakan istilah fundamentalisme dan dengan mudahnya mencap kelompok islam lainnya dengan istilah yang kontroversial ini. Bahkan yang lebih ekstrim ialah memandankan istilah fundamentalisme dengan radikalisme, ${ }^{25}$ fundamentalisme dengan tradisionalis, konservatif, dan revivalis. ${ }^{26}$ Bahkan beberapa penulis menjadikan sebagai derivatif dari gerakan islam sempalan. ${ }^{27}$

Meskipun begitu, dalam mengkaji fenomena fundamentalisme setidaknya bisa bertolah dari tiga paradigma. Pertama, paradigma islamic exceptionalism, menurut paradigma ini, teori-teori dalam ilmu sosial barat tidak bisa digunakan untuk menjelaskan fenomena fundamentalisme islam karena memiliki keunikan dan berbeda dengan fundamentalisme yang muncul di dunia lain, lebih-lebih yang muncul di barat. Kedua, paradigma comparative fundamentalism, menurut paradigma ini, fenomena fundamentalisme tidak unik karena merupakan bagian dari fenomena fundamentalisme secara global. Paradigma class analysis, paradigma ini menggunakan konsep ilmu-ilmu sosial untuk menjelaskan fenomena fundamentalisme islam. Paradigma ini memfokuskan pada analisi kelas dan perjuangan kelas sebagai faktor utama munculnya fundamentalisme islam. Hampir semua ilmuwan yang bertolak dari paradigma ketiga ini mengakui bahaya

\footnotetext{
24 John L. Esposito, Ancaman Islam: Mitos atau Realitas (Bandung: Mizan,1994) h. 17-18

${ }^{25}$ Syamsuddin Jurdio, op. cit., h 309-310

${ }^{26}$ Umi Sumbulah, Jurnal “Akademika”- PPS IAIN Sunan Ampel Surabaya 2004.

27 Al-Chaidar, Pemetaan Kelompok Islam Radikal dan Islam Fundamentalis di indonesia, Makalah disampaikan pada seminar di Universitas Malikussaleh, Lhokseumawe, Aceh.
} 
fundamentalisme terhadap perkembangan demokrasi, kebebasan sipilhak asasi manusia, kemajuan ilmu pengetahuan, etnik dan agama minoritas. ${ }^{28}$

Untuk memperjelas fenomena islam fundamentalisme dan militan ada beberapa kerangka yang diberikan sosiolog agama Marty sebagaimana yang diikuti Azyumardi Azra bahwa prisip islam fundamentalis adalah pertama oppositionalism (paham perlawanan) yang bersifat radikal terhadap ancaman yang dipandang membahayakan eksistensi agama, apakah dalam bentuk modernitas atau modernisme, sekularisasi dan tata nilai barat pada umumnya. Kedua, penolakan terhadap hermeunetika. Kaum fundamentalis menolak sikap kritis terhadap teks dan implementasinya. Teks al-quran harus dipahami secara literal sebagaimana adanya, karena nalar dipandang tidak mampu memberikan interprestasi yang tepat pada teks. Ketiga, penolakan terhadap pluralisme dan relativisme. Pluralisme merupakan hasil dari pemahaman dan sikap keagamaan yang tidak selaras dari pemahaman dan sikap keagamaan yang tidak selaras dengan pandangan kaum fundamentalisme merupakan bentuk dari relativisme keagamaan. Keempat, penolakan terhadap perkembangan historis dan sosiologis. Kaum fundamentalisme berpandangan bahwa perkembangan historis dan sosiologis telah membawa manusia semakin jauh dari doktrin literal kitab suci. Dalam kerangka ini masyarakat harus menyesuaikan perkembangannya, kalau perlu dengan kekerasan dengan teks kitab suci, bukan sebaliknya, teks atau penafsirannya yang mengikuti perkembangan masyarakat. Kaum fundamentalis bersifat a-historis dan a-sosiologis bertujuan kembali kepada bentuk masyarakat ideal seperti zaman kaum salaf yang dipandang mengejawantahkan kitab suci yang sempurna. ${ }^{29}$

\section{PENUTUP}

Teori untuk melihat ideologi melalui pendekatan kesejarahan sosial ide itu berasal dari Sosiologi Pengetahuan. Gagasan dan nilai-nilai dapat ditemukan dengan melihat aktor dan lembaga merumuskan suatu gagasan-gagasannya.

Ide yang muncul ketika terus mengalami transformasi dan perubahan ketika menghadapi realitas dan menjadi suatu gagasan yang berakar dan terkristalisasi inilah yang bisa disebutkan sebagai ideologi. Gerakan sosial keagamaan merupakan suatu perilaku kolektif yang melahirkan tindakan sosial dalam bentuk aktifitasaktifitas keagamaan. Perilaku kolektif ini didasarkan pada nilai-nilai yang terkandung dari ajaran dan dogma dari agama tersebut. Gerakan sosial keagamaan biasanya dipengaruhi oleh penekanan terhadap gagasan keagamaan yang diklasifikasikan dengan pesimistik, perfeksionis, legalistik, egosentrik dan esoteric.

${ }^{28}$ Masoud Kazemzadeh, Teaching Politic if Islam Fundamentalism, Political Science \& Politics, March, 1998. h. 2-6

29 Azyumardi Azra, Pergolakan politik islam dari Fundamentalisme, Modernisme Hingga Postmodernisme (Jakarta: Paramadina, 1996).h 109-110 
Oleh sebab itu gerakan sosial keagamaan berorientasi nilai bisa menjadi suatu ideologi ketika nilai-nilai itu coba diterapkan dalam kehidupan realitas.

\section{Daftar Pustaka}

Arifin Syamsul, Ideologi dan Praksis Gerakan Sosial Kaum Fundamentalis, (Malang: UMM Press, 2010).

Herbert Blumer, Social Movement dalam principal of Sociology, ed. Alfred Mclung Lee (New York; Barnes\&Noble, inc. 1966).

John B Thomson, Analisi Ideologi: Kriti Wacana Ideologi-ideologi Dunia, (Yogyakarta: Ircisod, 2003).

Lyman Tower Sargent, Ideologi-ideologi Politik Kontemporer: Sebuah Analisis Komparatif (Jakarta: Erlangga,1987).

Jorge Larrain, Konsep ideologi (Yogyakarta: LKPSM, 1986).

Andrew Heywood, Political Ideologies: An Introduction (London: Macmillan Education Ltd., 1992).

Riberu dkk, Menguak Mitos-Mitos Pembangunan: telaah Etis dan Kritis. (Jakarta: Gramedia,1986).

Miftah Toha, Birokrasi Politik di Indonesia (Jakarta: Rajawali, 2003).

Soerjanto Poespowardojo, dalam Oetojo Oesman dan Alfian, Pancasila Sebagai Ideologi dalam Berbagai Bidang Kehidupan bermasyarakat, Berbangsa, dan Bernegara, (Surabaya: Karya Anda, 1993).

R. Hrair Dekmeijian, Islamic Revival: Catalysts, Categories, and Consequences, dalam The politics of islamic revivalism, ed. Shirean T. Hunter (Bloomington anf Indianapolish, Indiana University Press, 1998).

Jan Pakulski, Sosial movement and class: The Decline of the Marxist Paradigm.

Laode Ida. Gerakan Sosial Kelompok Nahdatul Ulama (NU) Progresif, Disertai Universitas Indonesia, Jakarta, 2001.

John Naisbitt, Nana Naisbitt, dan Doulas Philip. High Tech, High Touch: Pencarian Makna di tengah Perkembangan Pesat Teknologi (Bandung: Mizan, 2001).

Nurcholish Madjid, Kaki Langit Peradaban Islam (Jakarta: Paramadina, 1997).

James W. Vander Zanden, Sociology the Core (New York: McGraw-Hill Publishing Company, 1990).

John J. Macionis, Sociology (New Jersey: Prentice Hall, 1991).

Kumanto Sunanto, Pengantar Sosiologi (Jakarta: Lembaga Penerbit Fakultas Ekonomi Universitas Indonesia, 1993).

Yusril Ihza Mahendra, Fundamentalisme dan Modernisme Politik Islam (Jakarta: Paramadina, 1999). 
Syarifuddin Jurdi, Pemikiran Politik Islam Indonesia: Pertauan Negara, Khalifah, Masyarakat Madani dan Demokrasi. (Yogyakarta: Pustaka Pelajar, 2008).

Mark Jurgensmeyer, Menantang Negara Sekuler: Kebangkitan Global Nsionalisme Religius (Bandung: Mizan, 1998).

John L. Esposito, Ancaman Islam: Mitos atau Realitas (Bandung: Mizan,1994).

Umi Sumbulah, Jurnal “Akademika”- PPS IAIN Sunan Ampel Surabaya 2004.

Al-Chaidar, Pemetaan Kelompok Islam Radikal dan Islam Fundamentalis di indonesia, Makalah disampaikan pada seminar di Universitas Malikussaleh, Lhokseumawe, Aceh.

Masoud Kazemzadeh, Teaching Politic if Islam Fundamentalism, Political Science \& Politics, March, 1998.

Azyumardi Azra, Pergolakan politik islam dari Fundamentalisme, Modernisme Hingga Post-modernisme (Jakarta: Paramadina, 1996). 